\title{
Transcriptome responses to aluminum stress in roots of aspen (Populus tremula)
}

\author{
Nadine Grisel', Stefan Zoller ${ }^{2,6}$, Marzanna Künzli-Gontarczyk², Thomas Lampart ${ }^{1,3,7}$, Martin Münsterkötter ${ }^{4}$, \\ Ivano Brunner', Lucien Bovet ${ }^{5,8}$, Jean-Pierre Métraux ${ }^{5}$, Christoph Sperisen ${ }^{1 *}$
}

\begin{abstract}
Background: lonic aluminum (mainly $\mathrm{Al}^{3+}$ ) is rhizotoxic and can be present in acid soils at concentrations high enough to inhibit root growth. Many forest tree species grow naturally in acid soils and often tolerate high concentrations of Al. Previously, we have shown that aspen (Populus tremula) releases citrate and oxalate from roots in response to $\mathrm{Al}$ exposure. To obtain further insights into the root responses of aspen to $\mathrm{Al}$, we investigated root gene expression at Al conditions that inhibit root growth.

Results: Treatment of the aspen roots with $500 \mu \mathrm{M}$ Al induced a strong inhibition of root growth within $6 \mathrm{~h}$ of exposure time. The root growth subsequently recovered, reaching growth rates comparable to that of control plants. Changes in gene expression were determined after $6 \mathrm{~h}, 2 \mathrm{~d}$, and $10 \mathrm{~d}$ of Al exposure. Replicated transcriptome analyses using the Affymetrix poplar genome array revealed a total of 175 significantly up-regulated and 69 down-regulated genes, of which $70 \%$ could be annotated based on Arabidopsis genome resources. Between $6 \mathrm{~h}$ and $2 \mathrm{~d}$, the number of responsive genes strongly decreased from 202 to 26, and then the number of changes remained low. The responses after $6 \mathrm{~h}$ were characterized by genes involved in cell wall modification, ion transport, and oxidative stress. Two genes with prolonged induction were closely related to the Arabidopsis Al tolerance genes ALS3 (for Al sensitive 3) and MATE (for multidrug and toxin efflux protein, mediating citrate efflux). Patterns of expression in different plant organs and in response to $\mathrm{Al}$ indicated that the two aspen genes are homologs of the Arabidopsis ALS3 and MATE.

Conclusion: Exposure of aspen roots to Al results in a rapid inhibition of root growth and a large change in root gene expression. The subsequent root growth recovery and the concomitant reduction in the number of responsive genes presumably reflect the success of the roots in activating Al tolerance mechanisms. The aspen genes ALS3 and MATE may be important components of these mechanisms.
\end{abstract}

\section{Background}

Acid soils are prevalent in many regions of the world and present a range of stresses to plants. One of the major stresses caused by these soils is aluminum $(\mathrm{Al})$, which is solubilized by the acidity into the soil solution. Soluble $\mathrm{Al}$ exists in its most toxic form as $\mathrm{Al}^{3+}$, which can inhibit root growth in many plant species at micromolar concentrations. The resulting reduced and damaged root system limits the capacity of plants to uptake water and nutrients, and increases their susceptibility to other stresses.

\footnotetext{
* Correspondence: christoph.sperisen@wsl.ch

'Swiss Federal Institute for Forest, Snow and Landscape Research (WSL),

Zürcherstrasse 111, CH-8903 Birmensdorf, Switzerland Full list of author information is available at the end of the article
}

The mechanisms by which $\mathrm{Al}$ inhibits root growth are not well understood, despite extensive physiological investigations. The root apex is the most sensitive part of the root to $\mathrm{Al}$ because it is the site of cell division and cell elongation $[1,2]$. Since $\mathrm{Al}$ is so reactive, it can interact with multiple structures in the apoplasm and symplasm of root cells. In the cell wall, Al primarily binds to the pectin matrix and thereby alters the physical properties of the cell wall $[3,4]$. In the symplasm, sites of $\mathrm{Al}$ interaction include membrane constituents, ion channels, metabolic enzymes, components of signaling pathways, members of the cytoskeleton, and the DNA $[3,5]$. Although some of the resulting cellular alterations have been proposed to affect cell division or cell elongation, a recent study conducted in Arabidopsis
C Biomed Central 
thaliana indicates that it is not Al toxicity that is directly responsible for the inhibition of root growth. Genetic and biochemical evidence suggest that the cells of the root apex have an ATR-controlled mechanism to monitor Al-induced DNA damage [6]. In plants exposed to $\mathrm{Al}$, this mechanism activates blockage of cell cycle progression and thus root growth. This active response of roots to $\mathrm{Al}$ may not protect individual plants, but it may help to safeguard plant populations by preventing the passage of damaged DNA to subsequent plant generations [6].

Plant species vary considerably in their degree of $\mathrm{Al}$ tolerance, and even genotypes within the same plant species vary in their ability to cope with Al. The mechanisms providing enhanced $\mathrm{Al}$ tolerance can be classified into external and internal mechanisms [5,7]. The best-documented external mechanism is the efflux of organic acid anions, such as malate, citrate, and oxalate, from the roots in response to $\mathrm{Al}$ exposure [8]. These organic acid anions effectively chelate $\mathrm{Al}$ and thereby detoxify $\mathrm{Al}$ in the rhizosphere. Other proposed external mechanisms involve secretion of proteins [9], root-mediated increase of the rhizosphere $\mathrm{pH}$ [10], and masking Al binding sites at the cell wall $[11,12]$. Proposed internal tolerance mechanisms include chelation of $\mathrm{Al}$ by organic acid anions or phenolic compounds and sequestration of $\mathrm{Al}$ in the vacuole [5].

The genes responsible for the Al-induced efflux of malate and citrate have been recently isolated and demonstrated to represent major genes for $\mathrm{Al}$ tolerance in several plant species [8]. The genes responsible for the efflux of malate belong to the $A L M T$ (for Al-activated malate transporter) gene family [13-15] and those involved in the efflux of citrate to the MATE (for multidrug and toxin efflux protein) gene family [16-20]. All these genes encode membrane proteins, consistent with their role in facilitating the efflux of organic acid anions. Additional genes with putative roles in Al tolerance have been identified in $\mathrm{Al}$-sensitive mutants of rice (Oryza sativa) and Arabidopsis. The rice mutants star1 (for sensitive to $\mathrm{Al}$ rhizotoxicity 1 ) and star 2 were found to be mutated in genes encoding two proteins that form together an ATP-binding cassette $(\mathrm{ABC})$ transporter [21]. This complex mediates the transport of UDP-glucose to the cell wall, where the molecule is believed to play a role in masking Al binding sites. Similarly to star1 and star2, the Al-sensitive mutants als1 (for $\mathrm{Al}$ sensitive 1) and als 3 of Arabidopsis are mutated in genes encoding $A B C$ transporter-like proteins [22,23]. Although the substrate of these proteins is not known, the mutant phenotypes and patterns of gene expression have led to the proposal that the two proteins transport and sequester $\mathrm{Al}$ to confer $\mathrm{Al}$ tolerance. ALS1 is believed to be involved in the intracellular transport of
Al to the vacuole [22], whereas ALS3 appears to be necessary for the long-distance transport of $\mathrm{Al}$ to the aerial parts of the plant [23].

Further insight into the molecular mechanisms involved in $\mathrm{Al}$ toxicity and tolerance come from gene expression analyses. Genome-wide transcriptome analyses in roots of Arabidopsis have revealed a number of cellular processes that are altered in response to $\mathrm{Al}$ exposure. Examples are cell wall modification, protein metabolism, transport processes, and oxidative stress [24,25]. In maize (Zea mays), wheat (Triticum aestivum), and Medicago truncatula, gene expression was analyzed in plant lines with contrasting levels of $\mathrm{Al}$ tolerance [26-28]. These studies have led to the identification of several candidate genes for Al tolerance, including previously identified genes encoding organic acid efflux transporters, genes controlling levels of reactive oxygen species (ROS), as well as genes involved in pectin modification and immobilization of Al by phosphate.

Forest trees generally tolerate high concentrations of $\mathrm{Al}$ [29]. For example, seedlings of Norway spruce (Picea abies) and birch (Betula pendula) did not show any reduction in root growth at $\mathrm{Al}$ concentrations below 0.3 and $3 \mathrm{mM}$, respectively [30,31]. In contrast, $\mathrm{Al}$ concentrations as low as $50 \mu \mathrm{M}$ tend to affect the root growth of Arabidopsis and several crop plants (e.g. [24,28,32]). Since many forest tree species grow naturally in acid soils, it appears likely that such species have developed adaptive mechanisms that enable them to tolerate high $\mathrm{Al}$ conditions. Analyses of the root responses to $\mathrm{Al}$ in forest trees may thus broaden our understanding of $\mathrm{Al}$ tolerance mechanisms in plants.

In a previous study, we used clonal aspen (Populus tremula, clone Birmensdorf) to investigate Al-induced efflux of organic acid anions from roots [33]. The results showed that $\mathrm{Al}$ concentrations $\geq 200 \mu \mathrm{M}$ induced the efflux of citrate, while Al concentrations $\geq 500 \mu \mathrm{M}$ enhanced the efflux of oxalate. At these concentrations, $\mathrm{Al}$ did not cause any visible symptoms at the root tips, indicating that the aspen clone examined tolerates high concentrations of Al. Using the same aspen clone, we investigated temporal patterns of root gene expression under $\mathrm{Al}$ stress. Changes in gene expression were assessed by application of the Affymetrix poplar genome array. The expression of selected genes was further analyzed by reverse-transcription PCR.

\section{Results}

\section{Effect of Al on root growth and callose formation}

To determine plant treatment conditions suitable for gene expression profiling, we examined the effect of $\mathrm{Al}$ on root growth. Clonal aspen was treated with either no $\mathrm{Al}$ or increasing concentrations of $\mathrm{Al}$ up to $1000 \mu \mathrm{M}$ for 


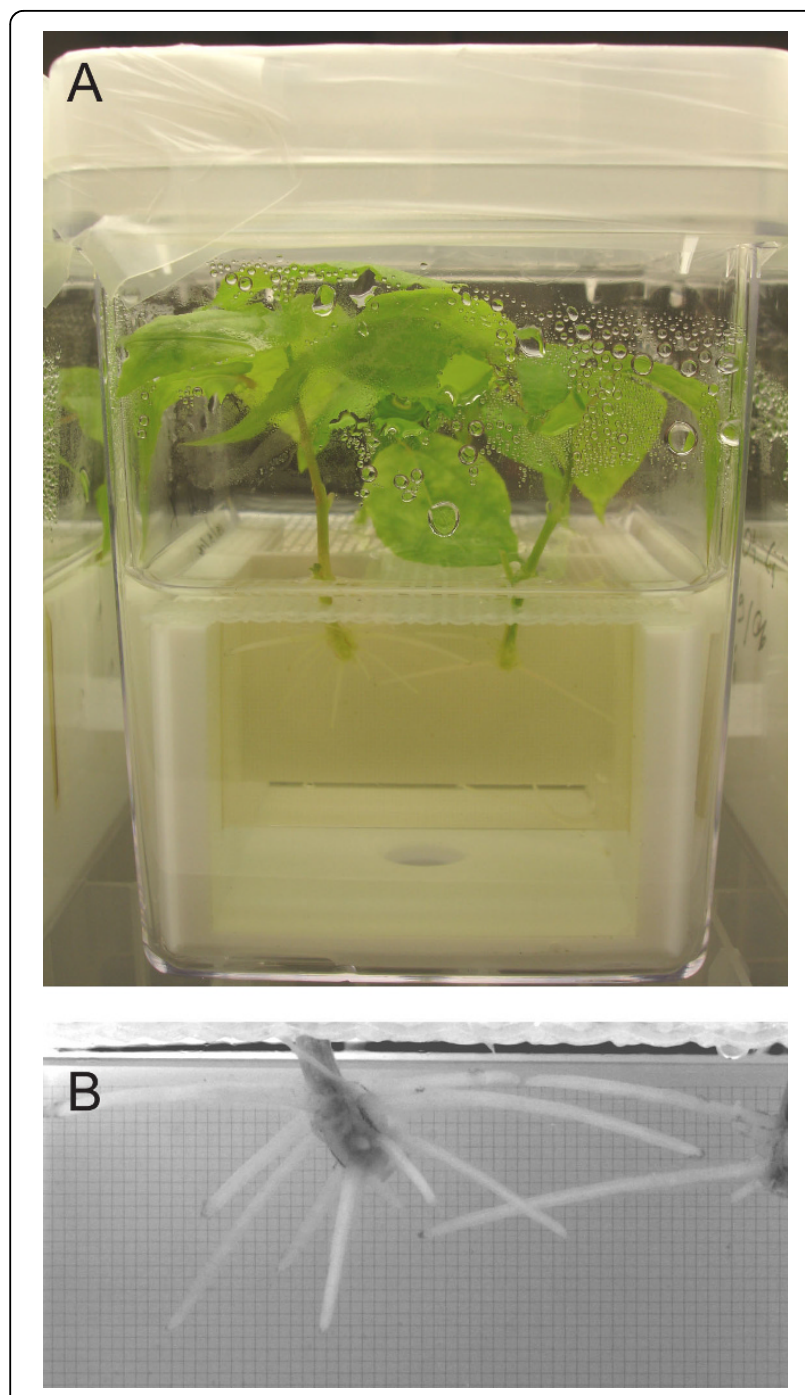

Figure 1 Solution culture of clonal aspen (Populus tremula). A Solution cultures were established in modified Magenta boxes. B Root growth was photographically monitored. Glass slides with a $5 \mu \mathrm{m}$ grid were used as a reference to measure root growth.

$2 \mathrm{~d}$ in solution culture (Fig. 1). Exposure of the roots to $100 \mu \mathrm{M} \mathrm{Al}$ did not affect their growth (Fig. 2A). In contrast, 250,500 , and $1000 \mu \mathrm{M} \mathrm{Al}$ caused a rapid and strong inhibition of root growth, with a reduction in growth rate of $\geq 40 \%$ observed after $6 \mathrm{~h}$. During prolonged $\mathrm{Al}$ exposure, the root growth of plants treated with 250 and $500 \mu \mathrm{M} \mathrm{Al}$ partially recovered, while that of plants treated with $1000 \mu \mathrm{M}$ further decreased, although not significantly $(p>0.1)$. As a further indicator of Al toxicity, we quantified callose, which accumulates in many plant species upon $\mathrm{Al}$ exposure [3]. The content of callose in the root tips increased with $\mathrm{Al}$ in the medium, with a significant increase observed at $\mathrm{Al}$ concentrations $\geq 250 \mu \mathrm{M}$ (Fig. 2B).
Root growth of plants used for gene expression profiling Based on the results of the dose-response experiment, plants were treated with $500 \mu \mathrm{M} \mathrm{Al}$ for gene expression profiling. Treatment with $500 \mu \mathrm{M}$ was preferred over $1000 \mu \mathrm{M}$, which tended to cause necrotic lesions at the root tips. The time points selected were $6 \mathrm{~h}, 54 \mathrm{~h}$ (designated as $2 \mathrm{~d}$ ), and $246 \mathrm{~h}(10 \mathrm{~d})$. The $6 \mathrm{~h}$ time point marked the rapid $\mathrm{Al}$-induced inhibition of root growth. The 2 and $10 \mathrm{~d}$ time points represented the period of root growth recovery. Since some plant genes are regulated by a diurnal rhythm and circadian clock, the exact duration of the treatments were designed such that the roots could be sampled at the same time each. During the $10 \mathrm{~d}$ treatment, the culture medium was exchanged every $2 \mathrm{~d}$ to maintain a constant $\mathrm{Al}$ stress. Consistent with the results of the dose-response experiment, $\mathrm{Al}$ induced a rapid inhibition of root growth $(68 \%$ reduction at $6 \mathrm{~h}$; Fig. 3A). The growth of roots treated with $\mathrm{Al}$ for 2 and $10 \mathrm{~d}$ gradually recovered (50\% reduction at $2 \mathrm{~d} ; 36 \%$ reduction at $10 \mathrm{~d}$ ). Al concentrations of the culture medium decreased only slightly during the 2 $\mathrm{d}$ treatment periods (on average by $36.7 \pm 13.9 \mu \mathrm{M}$ ), and the $\mathrm{pH}$ remained constant $(\mathrm{pH} 4.0 \pm 0.1)$. Therefore, the increase in root growth could not be explained by either a possible decrease of $\mathrm{Al}$ in the culture medium due to the uptake of $\mathrm{Al}$ by the plants, or altered $\mathrm{Al}$ speciation due to $\mathrm{pH}$ change.

\section{Changes in gene expression}

Gene expression profiles were determined using the Affymetrix poplar genome array, interrogating over 56,000 transcripts and gene predictions. To detect genes that are significantly regulated by $\mathrm{Al}$, we employed an approach that allowed an estimation of the false discovery rate (FDR) in multiple testing. The $q$-value, which is a positive FDR analogue of the $p$-value [34], was set to 0.15 . As a further criterion, we used a two-fold change cut-off. By these criteria and after removing redundant probe sets, a total of 244 genes were differentially expressed. Treatment of the roots for $6 \mathrm{~h}$ resulted in the up-regulation of 152 genes and the down-regulation of 50 genes (Fig. 3B; C). These numbers decreased significantly when the roots were treated for $2 \mathrm{~d}$ (26 genes up-regulated, 1 down-regulated). Of the induced genes at this time point, 20 were also induced after $6 \mathrm{~h}$. Treatment of the roots for $10 \mathrm{~d}$ yielded a similar low number of responsive genes ( 21 genes up-regulated, 18 downregulated). Three genes were induced across all three time points.

\section{Validation of microarray data}

The microarray data were independently verified by realtime reverse transcription PCR (qRT-PCR). Eight genes 


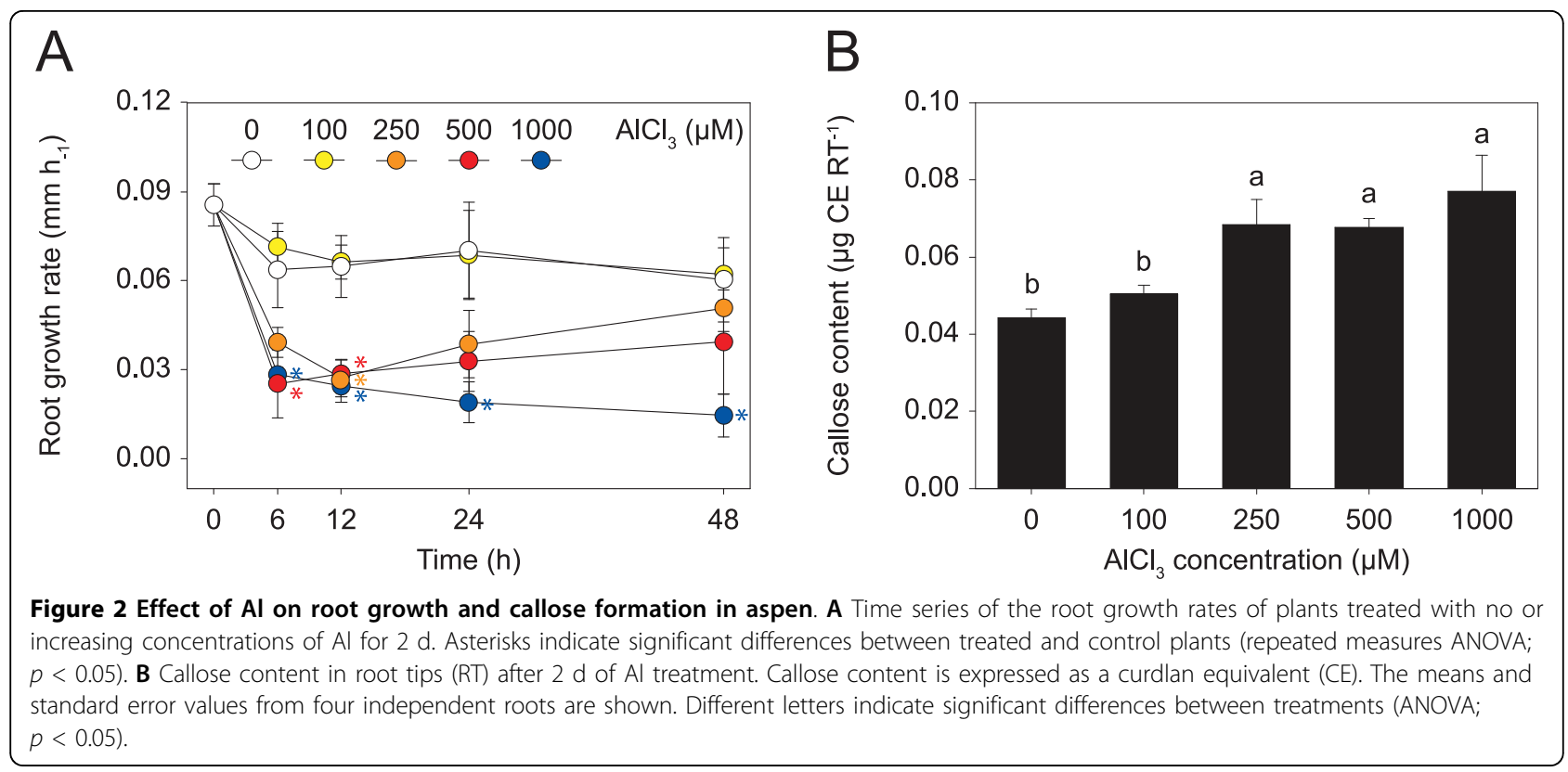

were analyzed, displaying a wide range of expression profiles. Transcripts were quantified relative to the actin 9 (ACT9) gene, which was isolated and sequenced in this study. The qRT-PCR analyses were performed with RNA from the microarray experiment (18 samples) and with RNA from an independent Al treatment experiment (2 samples). Six genes were tested with the RNA from both experiments. A significant correlation was found between the microarray and qRT-PCR data $\left(R^{2}=0.91 ; p<0.01\right.$; Fig. 4A). The magnitude of the relative changes in transcript abundance did not differ greatly between the two techniques. Exceptions were two strongly induced genes encoding a basic pathogenesis-related protein and a family
3 sulfate transporter: expression differences measured by qRT-PCR were 10 times greater than those measured by microarrays, probably due to the fact that qRT-PCR has a wider dynamic range than microarrays [35]. To examine the validity of using $A C T 9$ as a reference gene, absolute qRT-PCR was performed. The analysis showed that the expression of the gene did not change significantly during the $10 \mathrm{~d}$ treatment ( $p>0.6$; Fig. $4 \mathrm{~B})$.

\section{Annotation and functional categorization of Al-responsive genes}

BLASTX searches against the Arabidopsis protein database allowed 172 of the responsive genes to be annotated
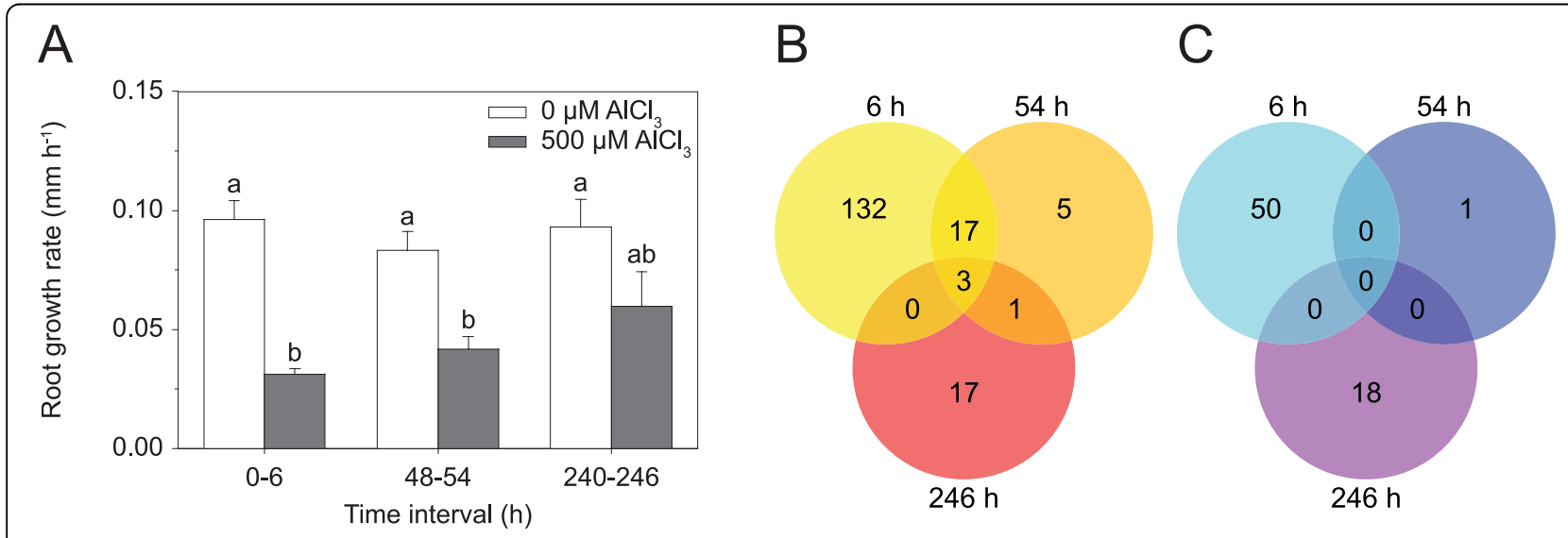

Figure 3 Aspen genes with significantly altered expression in Al-treated root tips compared to control root tips. A Root growth rates of plants used for the gene expression profiling. Roots were treated with $500 \mu \mathrm{M} \mathrm{Al}$ for $6 \mathrm{~h}, 54 \mathrm{~h}$, and $246 \mathrm{~h}$. During the $246 \mathrm{~h}$ treatment, the culture medium was exchanged every $2 \mathrm{~d}$ to maintain a constant Al stress. Means and standard error values from four independent roots are shown. Different letters indicate significant differences between treatments (ANOVA; $p<0.05$ ). Number of up-regulated genes (B) and downregulated genes $(\mathbf{C})$ after 6 h, 54 h, and 246 h of Al treatment ( $\geq 2$-fold change in expression). 


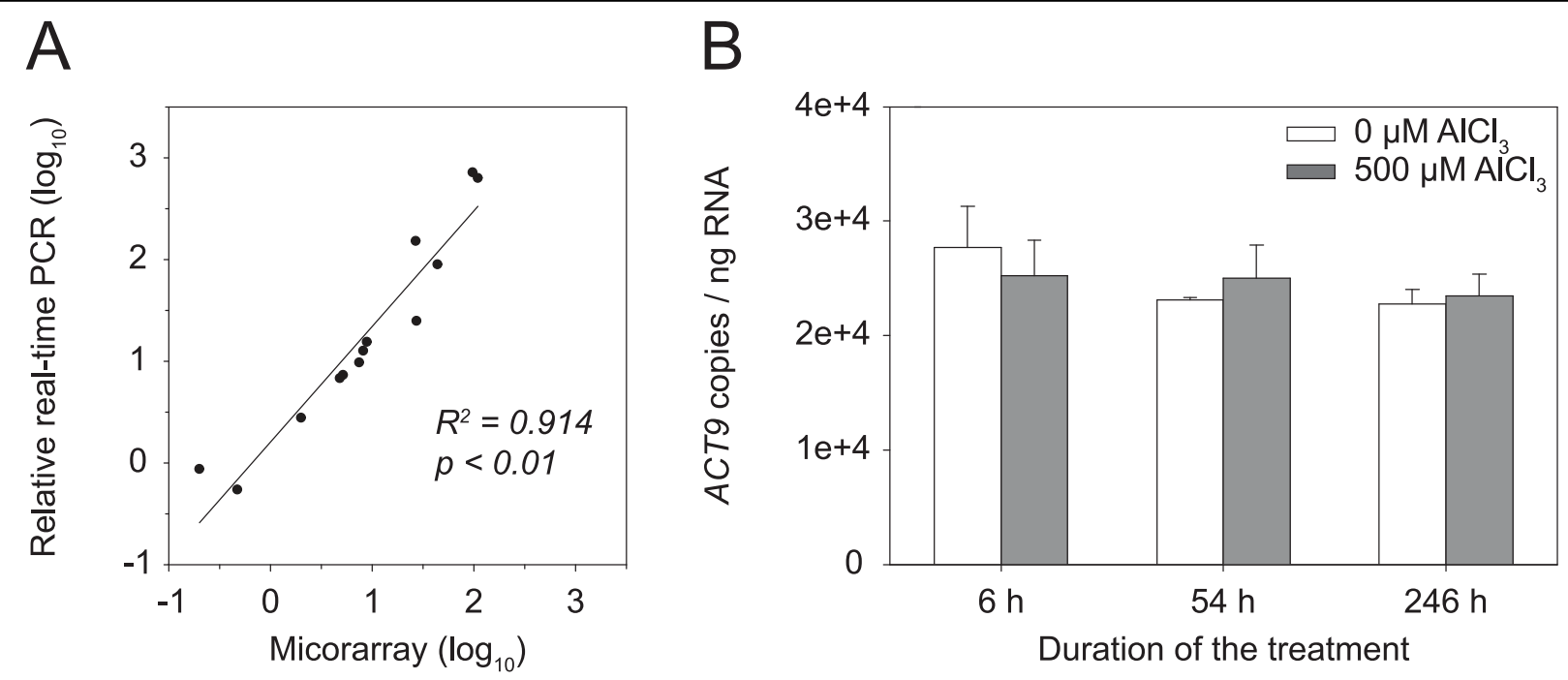

Figure 4 Validation of microarray data. A Relationship between microarray and qRT-PCR data. Transcript levels of eight differentially expressed genes were quantified by qRT-PCR relative to ACT9. The fold changes in gene expression in response to Al treatment were $\log _{10}$ transformed. The microarray data were plotted against the qRT-PCR data. B Expression levels of ACT9 in the root samples used for microarray experiments. ACT9 transcript levels did not significantly change during the $10 \mathrm{~d}$ Al treatment (ANOVA; $p>0.6$ ). The means and standard error values from three independent samples are shown.

(expectation $(E)$-value $\left.\leq 1 \times 10^{-10}\right)$. Additional 29 genes had matches to Arabidopsis genes with unknown functions, and 44 genes had no detectable similarity to Arabidopsis proteins $\left(E\right.$-value $\left.\geq 1 \times 10^{-4}\right)$. A complete list of the responsive genes is presented in additional file 1 .

To identify biological processes, the genes with known functions were classified using the Munich Information Center for Protein Sequences (MIPS) functional catalogue [36]. The genes present on the microarray were also classified to allow identification of categories whose genes were over-represented compared to the genes present on the microarray. These analyses were carried out for the genes regulated after $6 \mathrm{~h}$ and for the combined set of genes regulated after 2 and $10 \mathrm{~d}$. Top-level categories and subcategories with an enrichment $p$-value < 0.05 and a FDR $<0.05$ were regarded as pertinent to the time points examined. By these criteria, genes assigned to the top-level categories 'metabolism' and 'cell rescue and defense' were enriched after $6 \mathrm{~h}$ (Fig. 5A; additional file 2). Within the 'metabolism' category, the genes related to 'carbohydrate metabolism' were enriched and included several genes involved in cell wall modification (additional file 2). Additional enriched genes related to cell wall modification were assigned to the top-level category 'biogenesis of cellular components'. The toplevel category 'cell rescue and defense' included a number of enriched genes related to 'oxidative stress response' and 'detoxification'. An additional major group of enriched genes had functions in 'ion transport'. Smaller groups of enriched genes were related to 'cell death' and 'plant signaling molecules'. Genes implicated in 'ion transport' and 'carbohydrate metabolism' were also enriched during prolonged $\mathrm{Al}$ exposure, but their number was small (additional file 2). Additional genes enriched during prolonged $\mathrm{Al}$ exposure were assigned to the top-level categories 'energy' and 'interaction with the environment' (Fig. 5B).

\section{Genes related to cell wall modification}

All the genes recorded that are related to cell wall modification were regulated after $6 \mathrm{~h}$ of $\mathrm{Al}$ exposure (Table $1)$. Nine of these genes have functions in the modification of pectin. A pectin methylesterase gene, two pectate lyase genes, and two galacturonosyltransferase genes were down-regulated. Of the three pectin methylesterase inhibitor genes identified, two were down-regulated and the other induced. Additional genes encoded proteins that target cellulose and xyloglucan. The three endo-1,4$\beta$-glucanase and three xyloglucan endotransglucosylase/ hydrolase genes recorded showed contrasting patterns of up- and down-regulated expression.

\section{Genes related to ion transport}

The regulated genes encoding ion transporters included both cation and anion transporters. With the exception of a ferritin gene, all the ion transporters were induced. A two-pore $\mathrm{K}^{+}$channel gene was closely related to the Arabidopsis gene TPK1, which is a key regulator of $\mathrm{K}$ homeostasis [37]. Two genes encoded CorA-like Mg transporters, belonging to a class of transmembrane 


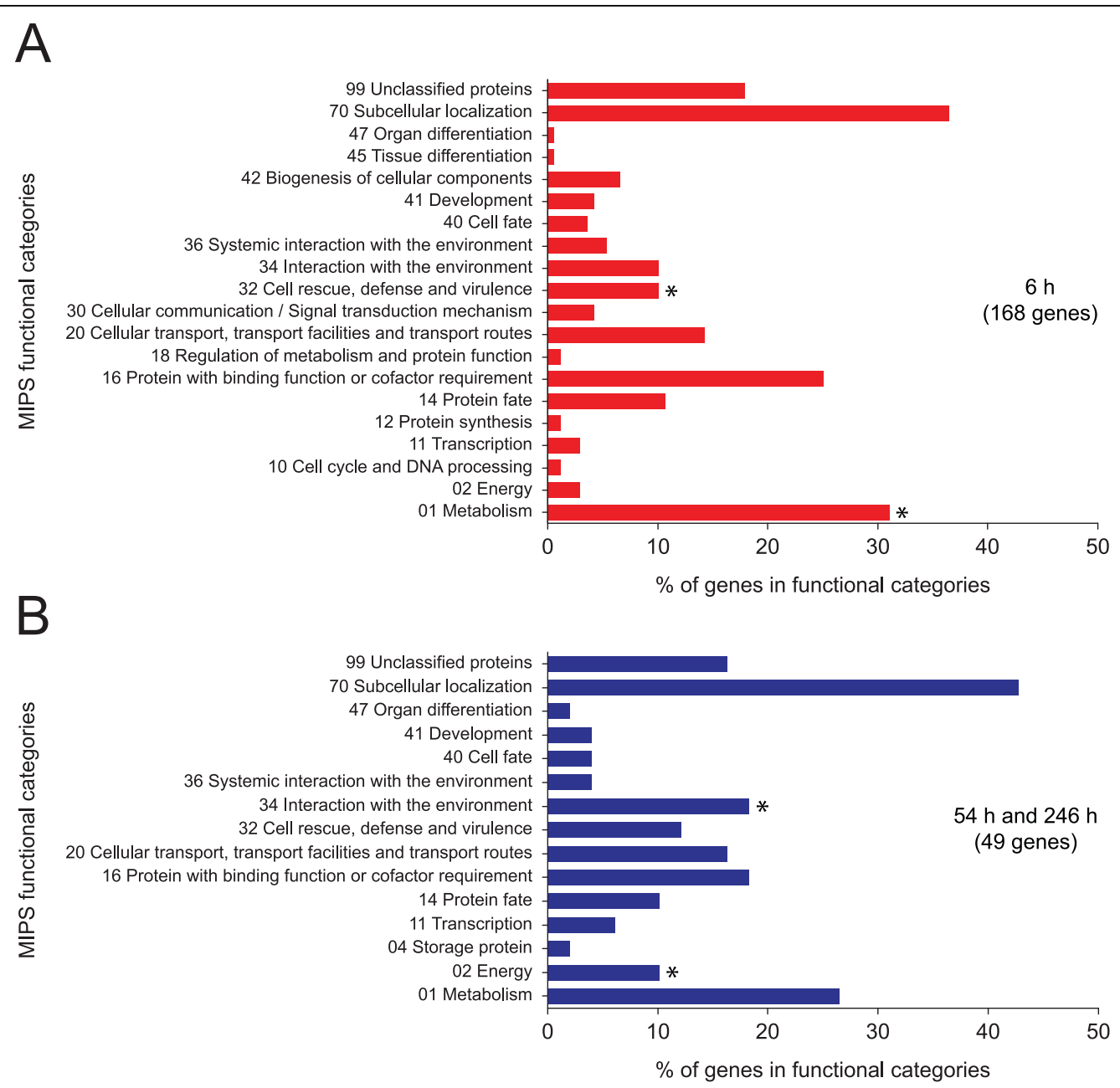

Figure 5 Functional categorization of the differentially expressed aspen genes using the Munich Information Center for Protein Sequences (MIPS) functional catalogue. Categories of the differentially expressed genes after $6 \mathrm{~h}$ of Al exposure (A), and the combined set of genes differentially expressed after 2 and $10 \mathrm{~d}$ of Al exposure (B). Categories whose members were enriched are indicated by asterisks $(p<0.05$, FDR $<0.05)$.

proteins that are suggested to function in the uptake and intracellular transport of $\mathrm{Mg}$ [38]. The anion transporters were composed of a family 4 phosphate transporter and two family 3 sulfate transporter genes. The encoded family 4 phosphate transporter was related to the Arabidopsis protein PHT4;6, proposed to be involved in the biosynthesis of cell wall polysaccharides [39]. One of the encoded sulfate transporters was related to the Arabidopsis SULTR3;5, a protein functioning in the root-to-shoot transport of sulfate [40].

\section{Genes related to oxidative stress}

Three of the regulated genes related to oxidative stress belong to the network of genes that control levels of ROS [41]. An alternative oxidase and a Fe superoxide dismutase gene were up-regulated, while a glutaredoxin gene was down-regulated. Additional genes encoded tau-type glutathione $S$-transferases and peroxidases.
Individual members of these gene families showed contrasting patterns of up- and down-regulated expression.

\section{Identification of putative Al tolerance genes}

Among the regulated genes encoding transport facilitators, there were two genes that may play a role in $\mathrm{Al}$ tolerance. One was related to the Arabidopsis Al tolerance gene ALS3 [23]. The other belonged to the MATE gene family and was related to the Arabidopsis citrate efflux transporter gene MATE [18] and to FRD3 (for ferric reductase defective 3 ), which encodes a citrate transporter responsible for loading Fe into the xylem [42]. Both aspen genes were induced: $A L S 3$ was up-regulated at all three time points, and MATE at $6 \mathrm{~h}$ and $2 \mathrm{~d}$.

To examine whether the genes identified by microarrays are indeed genes related to the Arabidopsis ALS3 and MATE, RT-PCR was performed and the PCR products were sequenced. In the case of $A L S 3$, the entire 
Table 1 Selected genes differentially expressed in Al-treated aspen roots.

\begin{tabular}{|c|c|c|c|c|c|c|}
\hline \multirow{2}{*}{$\begin{array}{l}\text { Affymetrix probe } \\
\text { set ID }\end{array}$} & \multirow[b]{2}{*}{ Gene model name ${ }^{b}$} & \multirow[b]{2}{*}{ AGI $n^{\circ C}$} & \multirow[b]{2}{*}{ Annotation of best hit in Arabidopsis thaliana genome ${ }^{\mathrm{d}}$} & \multicolumn{3}{|c|}{ Fold change } \\
\hline & & & & $6 \mathrm{~h}$ & $2 d$ & $10 \mathrm{~d}$ \\
\hline \multicolumn{7}{|l|}{ Cell wall } \\
\hline PtpAffx.21218.1.S1_at & eugene3.00280166 & AT3G13750 & Beta-galactosidase 1 (BGAL1; GH35) & 0.2 & $0.5^{\mathrm{ns}}$ & $0.5^{\mathrm{ns}}$ \\
\hline $\begin{array}{l}\text { PtpAffx.122394.1. } \\
\text { S1_at }\end{array}$ & gw1.1.26.1 & AT5G64570 & Beta-xylosidase 4 (XYL4; GH3) & 0.2 & $0.8^{\mathrm{ns}}$ & $1.3^{\text {ns }}$ \\
\hline $\begin{array}{l}\text { PtpAffx.212738.1. } \\
\text { S1_at }\end{array}$ & $\begin{array}{l}\text { estExt_fgenesh4_pg. } \\
\text { C_LG_XV0425 }\end{array}$ & AT5G62620 & Galactosyltransferase family protein & 2.1 & $1.0^{\mathrm{ns}}$ & $1.2^{\text {ns }}$ \\
\hline Ptp.7955.1.S1_at & gw1.VIII.37.1 & AT1G24170 & Galacturonosyltransferase-like 8 (GATL8; GT9) & 0.5 & $0.7^{\text {ns }}$ & $1.0^{\mathrm{ns}}$ \\
\hline $\begin{array}{l}\text { PtpAffx.208384.1. } \\
\text { S1_at }\end{array}$ & gw1.VIII.37.1 & AT1G70090 & Galacturonosyltransferase-like 9 (GATL9; GT8) & 0.5 & $0.8^{\text {ns }}$ & $1.1^{\mathrm{ns}}$ \\
\hline $\begin{array}{l}\text { PtpAffx.209224.1. } \\
\text { S1_at }\end{array}$ & $\begin{array}{l}\text { fgenesh4_pg. } \\
\text { C_LG_X001601 }\end{array}$ & AT1G65610 & Endo-1,4-beta-glucanase Korrigan 2 (KOR2; GH9) & 2.1 & $1.3^{\text {ns }}$ & $1.0^{\mathrm{ns}}$ \\
\hline $\begin{array}{l}\text { PtpAffx.207811.1. } \\
\text { S1_at }\end{array}$ & $\begin{array}{l}\text { estExt_fgenesh4_pg. } \\
\text { C_LG_VIII0680 }\end{array}$ & AT1G65610 & Endo-1,4-beta-glucanase Korrigan 2 (KOR2; GH9) & 2.9 & $1.3^{\text {ns }}$ & $1.0^{\mathrm{ns}}$ \\
\hline Ptp.4073.1.S1_s_at & $\begin{array}{l}\text { estExt_fgenesh4_pg. } \\
\text { C_LG_XIV0665 }\end{array}$ & AT4G02290 & Endo-1,4-beta-glucanase 17 (GH9) & 0.2 & $0.5^{\text {ns }}$ & $1.0^{\mathrm{ns}}$ \\
\hline $\begin{array}{l}\text { PtpAffx.116752.1. } \\
\text { A1_at }\end{array}$ & gw1.VIII.287.1 & AT3G26380 & Glycosyl hydrolase family protein $27(\mathrm{GH} 27)$ & 2.0 & 1.6 & $1.4^{\mathrm{ns}}$ \\
\hline PtpAffx.20309.1.S1_at & $\begin{array}{l}\text { estExt_fgenesh4_pg. } \\
\text { C_LG_X2099 }\end{array}$ & AT5G04500 & Glycosyl transferase family protein 64 (GT64) & 5.2 & 3.8 & $1.7^{\mathrm{ns}}$ \\
\hline Ptp.4642.1.S1_at & $\begin{array}{l}\text { estExt_fgenesh4_pg. } \\
\text { C_LG_XI1340 }\end{array}$ & AT1G30620 & UDP-D-xylose 4-epimerase 1 (UXE1) & 2.2 & 1.7 & $1.1^{\mathrm{ns}}$ \\
\hline PtpAffx.31211.1.A1_at & eugene3.00140929 & AT1G05560 & UDP-glucose transferase 1 (UGT1; GT1) & 6.4 & $0.8^{\text {ns }}$ & $1.5^{\mathrm{ns}}$ \\
\hline Ptp.160.1.S1_x_at & $\begin{array}{l}\text { fgenesh4_pm. } \\
\text { C_LG_II000873 }\end{array}$ & AT3G62830 & UDP-glucuronic acid decarboxylase 2 (UXS2) & 2.2 & $1.2^{\text {ns }}$ & $1.3^{\text {ns }}$ \\
\hline $\begin{array}{l}\text { PtpAffx.119179.1. } \\
\text { A1_at }\end{array}$ & gw1.1681.2.1 & AT5G48070 & $\begin{array}{l}\text { Xyloglucan endotransglucosylase/hydrolase } 20 \text { (XTH2O; } \\
\text { GH16) }\end{array}$ & 4.3 & $1.6^{\mathrm{ns}}$ & $1.7^{\mathrm{ns}}$ \\
\hline Ptp.2467.1.A1_x_at & gw1.XIX.2748.1 & AT4G03210 & Xyloglucan endotransglucosylase/hydrolase 9 (XTH9; GH16) & 0.3 & $0.6^{\text {ns }}$ & $1.1^{\mathrm{ns}}$ \\
\hline Ptp.3050.1.S1_s_at & $\begin{array}{l}\text { estExt_Genewise1_v1. } \\
\text { C_LG_XIV2162 }\end{array}$ & AT1G10550 & Xyloglucan:xyloglucosyltransferase 33 (XTH33; GH16) & 0.3 & $0.8^{\text {ns }}$ & $0.9^{\text {ns }}$ \\
\hline Ptp.4810.1.A1_s_at & $\begin{array}{l}\text { estExt_Genewise1_v1. } \\
\text { C_LG_III0932 }\end{array}$ & AT1G04680 & Pectate lyase family protein & 0.5 & $0.8^{\text {ns }}$ & $0.9^{\text {ns }}$ \\
\hline PtpAffx.1316.2.S1_s_at & eugene3.00010425 & AT1G04680 & Pectate lyase family protein & 0.2 & $1.0^{\mathrm{ns}}$ & $0.9^{\text {ns }}$ \\
\hline $\begin{array}{l}\text { PtpAffx.9932.3. } \\
\text { S1_a_at }\end{array}$ & eugene3.00030462 & AT1G53830 & Pectin methylesterase 2 (PME2) & 0.4 & $0.9^{\text {ns }}$ & $0.8^{\text {ns }}$ \\
\hline $\begin{array}{l}\text { PtpAffx.9932.2. } \\
\text { A1_s_at }\end{array}$ & $\begin{array}{l}\text { estExt_fgenesh4_pm. } \\
\text { C_290002 }\end{array}$ & AT3G14310 & Pectin methylesterase inhibitor 3 (PMEI3) & 0.5 & $1.0^{\mathrm{ns}}$ & $1.0^{\mathrm{ns}}$ \\
\hline Ptp.7635.1.S1_at & eugene3.00140717 & AT1G02810 & Pectin methylesterase inhibitor 7 (PMEl7) & 4.0 & $1.5^{\mathrm{ns}}$ & $0.9^{\text {ns }}$ \\
\hline $\begin{array}{l}\text { PtpAffx.207505.1. } \\
\text { S1_at }\end{array}$ & gw1.VIII.1476.1 & AT3G10720 & Pectin methylesterase inhibitor 25 (PMEI25) & 0.3 & $0.5^{\text {ns }}$ & $1.0^{\mathrm{ns}}$ \\
\hline Ptp.3290.1.S1_at & gw1.VII.2504.1 & AT5G08200 & Peptidoglycan-binding LysM domain-containing protein & 2.2 & $1.2^{\text {ns }}$ & $1.1^{\mathrm{ns}}$ \\
\hline Ptp.2725.1.S1_at & gw1.X.2924.1 & AT5G62150 & Peptidoglycan-binding LysM domain-containing protein & 3.1 & $1.2^{\text {ns }}$ & $1.2^{\mathrm{ns}}$ \\
\hline $\begin{array}{l}\text { PtpAffx.208179.1. } \\
\text { S1_at }\end{array}$ & eugene3.00081504 & AT2G23770 & Peptidoglycan-binding LysM domain-containing protein & 2.3 & $1.5^{\mathrm{ns}}$ & $1.1^{\mathrm{ns}}$ \\
\hline \multicolumn{7}{|l|}{ Transport } \\
\hline \multicolumn{7}{|l|}{ Ion transport } \\
\hline Ptp.6087.1.S1_at & eugene3.97260001 & AT5G01600 & Ferritin 1 (FER1) & $0.3^{\text {ns }}$ & $0.4^{\mathrm{ns}}$ & 0.3 \\
\hline PtpAffx.595.4.S1_s_at & $\begin{array}{l}\text { estExt_fgenesh4_pg. } \\
\text { C__1470038 }\end{array}$ & AT2G24520 & $\mathrm{H}^{+}$-ATPase 5 (HA5) & 2.3 & $1.5^{\mathrm{ns}}$ & $1.6^{\mathrm{ns}}$ \\
\hline $\begin{array}{l}\text { PtpAffx.208738.1. } \\
\text { S1_s_at }\end{array}$ & $\begin{array}{l}\text { estExt_fgenesh4_pm. } \\
\text { C_LG_X0276 }\end{array}$ & AT5G64560 & Mg transporter CorA-like family protein (MRS2-2) & 4.8 & $2.2^{\text {ns }}$ & $1.4^{\mathrm{ns}}$ \\
\hline PtpAffx.46328.1.A1_at & gw1.l.4154.1 & AT3G19640 & Mg transporter CorA-like family protein (MRS2-3) & 3.8 & 2.8 & $1.3^{\mathrm{ns}}$ \\
\hline $\begin{array}{l}\text { PtpAffx.204370.1. } \\
\text { S1_at }\end{array}$ & $\begin{array}{l}\text { fgenesh4_pg. } \\
\text { C_LG_IX000025 }\end{array}$ & AT5G44370 & Phosphate transporter 4;6 (PHT4;6) & 4.3 & $1.8^{\text {ns }}$ & $1.1^{\mathrm{ns}}$ \\
\hline PtpAffx.249.377.A1_at & fgenesh4_pm. & AT3G51895 & Sulfate transmembrane transporter 3;1 (SULTR3;1) & 2.4 & $1.3^{\text {ns }}$ & $1.0^{\mathrm{ns}}$ \\
\hline
\end{tabular}


Table 1 Selected genes differentially expressed in Al-treated aspen roots. (Continued)

\begin{tabular}{|c|c|c|c|c|c|c|}
\hline PtpAffx.63924.1.S1_at & eugene3.01570002 & AT5G19600 & Sulfate transmembrane transporter 3;5 (SULTR3;5) & 26.8 & 109.2 & $3.2^{\text {ns }}$ \\
\hline PtpAffx.46298.1.S1_at & $\begin{array}{l}\text { estExt_fgenesh4_pg. } \\
\text { C_LG_VIII0032 }\end{array}$ & AT5G55630 & Two pore $\mathrm{K}^{+}$channel 1 (TPK1) & 2.1 & $1.3^{\text {ns }}$ & $1.1^{\mathrm{ns}}$ \\
\hline \multicolumn{7}{|l|}{ Transport facilities } \\
\hline $\begin{array}{l}\text { PtpAffx.119032.1. } \\
\text { S1_s_at }\end{array}$ & gw1.XVI.2587.1 & AT2G37330 & Aluminum sensitive 3 (ALS3) & 44.4 & 27.5 & 5.2 \\
\hline Ptp.5171.1.S1_at & gw1.VI.655.1 & AT5G03910 & ABC transporter homolog $12(\mathrm{ATH} 12)$ & 2.5 & $1.4^{\mathrm{ns}}$ & $1.1^{\text {ns }}$ \\
\hline $\begin{array}{l}\text { PtpAffx.204839.1. } \\
\text { S1_at }\end{array}$ & gw1.IX.3299.1 & AT3G08040 & MATE (FRD3) & 8.9 & $4.2^{\text {ns }}$ & $1.7^{\mathrm{ns}}$ \\
\hline Ptp.2869.1.A1_at & gw1.1.5916.1 & AT1G30690 & $\begin{array}{l}\text { SEC } 14 \text { cytosolic factor family protein/phosphoglyceride } \\
\text { transfer family protein }\end{array}$ & 0.3 & $0.8^{\text {ns }}$ & $0.9^{\text {ns }}$ \\
\hline \multicolumn{7}{|l|}{$\begin{array}{l}\text { Oxidative stress } \\
\text { response }\end{array}$} \\
\hline Ptp.2903.1.A1_s_at & gw1.XII.485.1 & AT3G22370 & Alternative oxidase $1 \mathrm{~A}(\mathrm{AOX} 1 \mathrm{~A})$ & 8.6 & $1.5^{\mathrm{ns}}$ & $3.6^{\text {ns }}$ \\
\hline PtpAffx.56141.1.A1_at & grail3.0007029701 & AT5G20230 & Blue copper binding protein (BCB) & 2.4 & $1.4^{\mathrm{ns}}$ & $2.4^{\mathrm{ns}}$ \\
\hline $\begin{array}{l}\text { PtpAffx.153878.1. } \\
\text { A1_at }\end{array}$ & gw1.XV.2559.1 & AT5G51100 & Fe superoxide dismutase (FSD2) & $1.4^{\mathrm{ns}}$ & $1.5^{\mathrm{ns}}$ & 2.8 \\
\hline $\begin{array}{l}\text { PtpAffx.134361.1. } \\
\text { A1_s_at }\end{array}$ & eugene3.00031141 & AT1G64500 & Glutaredoxin family protein & 0.4 & 0.7 & $0.4^{\mathrm{ns}}$ \\
\hline $\begin{array}{l}\text { PtpAffx.2286.4. } \\
\text { S1_a_at }\end{array}$ & - & AT1G17180 & Glutathione S-transferase tau 25 (GSTU25) & 0.4 & $0.5^{\mathrm{ns}}$ & $1.9^{\text {ns }}$ \\
\hline $\begin{array}{l}\text { PtpAffx.23427.1. } \\
\text { S1_s_at }\end{array}$ & $\begin{array}{l}\text { estExt_fgenesh4_pg. } \\
\text { C_LG_VIII1530 }\end{array}$ & AT2G29420 & Glutathione S-transferase tau 7 (GSTU7) & 2.9 & $1.0^{\mathrm{ns}}$ & $1.5^{\mathrm{ns}}$ \\
\hline PtpAffx.29337.1.A1_at & eugene3.00030584 & AT5G67400 & Peroxidase 73 (P73) & 0.5 & $1.0^{\text {ns }}$ & $1.0^{\mathrm{ns}}$ \\
\hline $\begin{array}{l}\text { PtpAffx.36879.1. } \\
\text { A1_s_at }\end{array}$ & gw1.VII.698.1 & AT5G24070 & Peroxidase family protein & 0.5 & $0.7^{\mathrm{ns}}$ & $0.8^{\text {ns }}$ \\
\hline PtpAffx.43372.1.A1_at & $\begin{array}{l}\text { fgenesh4_pg. } \\
\text { C_LG_XVI000455 }\end{array}$ & AT5G06720 & Peroxidase, putative & 3.1 & $1.4^{\mathrm{ns}}$ & $0.9^{\text {ns }}$ \\
\hline PtpAffx.54628.1.S1_at & $\begin{array}{l}\text { estExt_fgenesh4_pg. } \\
\text { C_LG_XVI1240 }\end{array}$ & AT5G05340 & Peroxidase, putative & 13.3 & $1.7^{\mathrm{ns}}$ & $1.1^{\mathrm{ns}}$ \\
\hline PtpAffx.55376.1.S1_at & $\begin{array}{l}\text { fgenesh4_pg. } \\
\text { C_LG_XIV000840 }\end{array}$ & AT5G05340 & Peroxidase, putative & $2.0^{\mathrm{ns}}$ & $0.4^{\mathrm{ns}}$ & 0.1 \\
\hline
\end{tabular}

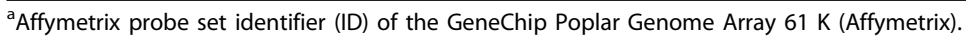

${ }^{\mathrm{b}}$ Preferred gene model name attributed by Poparray v1.2 http://aspendb.uga.edu/poparray.

'Arabidopsis genome identifier (AGI $n^{\circ}$ ).

${ }^{\mathrm{d}}$ Annotation of best hit in Arabidopsis genome with a E-value cut-off of $<0.05$.

${ }^{\mathrm{e}} \mathrm{C}$-compound and carbohydrate metabolism and cell wall.

fOxidative stress response and detoxification.

${ }^{\text {ns }}$ not significantly up- or down-regulated.

coding sequence was isolated. The predicted protein shared $79 \%$ sequence identity with the Arabidopsis ALS3 [23] and 71\% with STAR2 of rice [21]. All of these genes encode the transmembrane domain of $\mathrm{ABC}$ transporters and lack the ATP-binding cassette domain. In the case of MATE, approximately $80 \%$ was isolated. The predicted protein shared $60 \%$ sequence identity with the Arabidopsis MATE [18] and 62\% with FRD3 [43]. Similar degrees of sequence identities were found between the aspen MATE and MATE of sorghum (54\%) [16], barley (54\%) [17], and maize (56\%) [20].

\section{Expression of ALS3 and MATE}

Each of the three Arabidopsis genes ALS3, MATE, and FRD3 are characterized by a distinct pattern of expression. Under non-stressed conditions, $A L S 3$ is expressed in the phloem throughout the plant and in the root epidermis [23]. MATE and FRD3 are primarily expressed in the root $[18,43]$. Exposure to $\mathrm{Al}$ strongly induces $A L S 3$ and MATE in the root, but not FRD3 [18,23]. To examine whether the expression of the aspen ALS3 and MATE is coherent with that of the Arabidopsis ALS3 and $M A T E$, absolute qRT-PCR was carried out with RNA isolated from root, stem, and leaf tissue of a separate set of plants treated with either no $\mathrm{Al}$ or $500 \mu \mathrm{M} \mathrm{Al}$ for $2 \mathrm{~d}$. The results of the analysis showed that $A L S 3$ is expressed in all three tissues under non-stress conditions with little differences among the tissues (Fig. 6A). In contrast, $M A T E$ was more strongly expressed in the root than in the stem and leaves (Fig. 6B). Treatment of the plants with $\mathrm{Al}$ led to an induction of both genes (Fig. 6A; B). $A L S 3$ was strongly induced in the root (22.3-fold) and to 


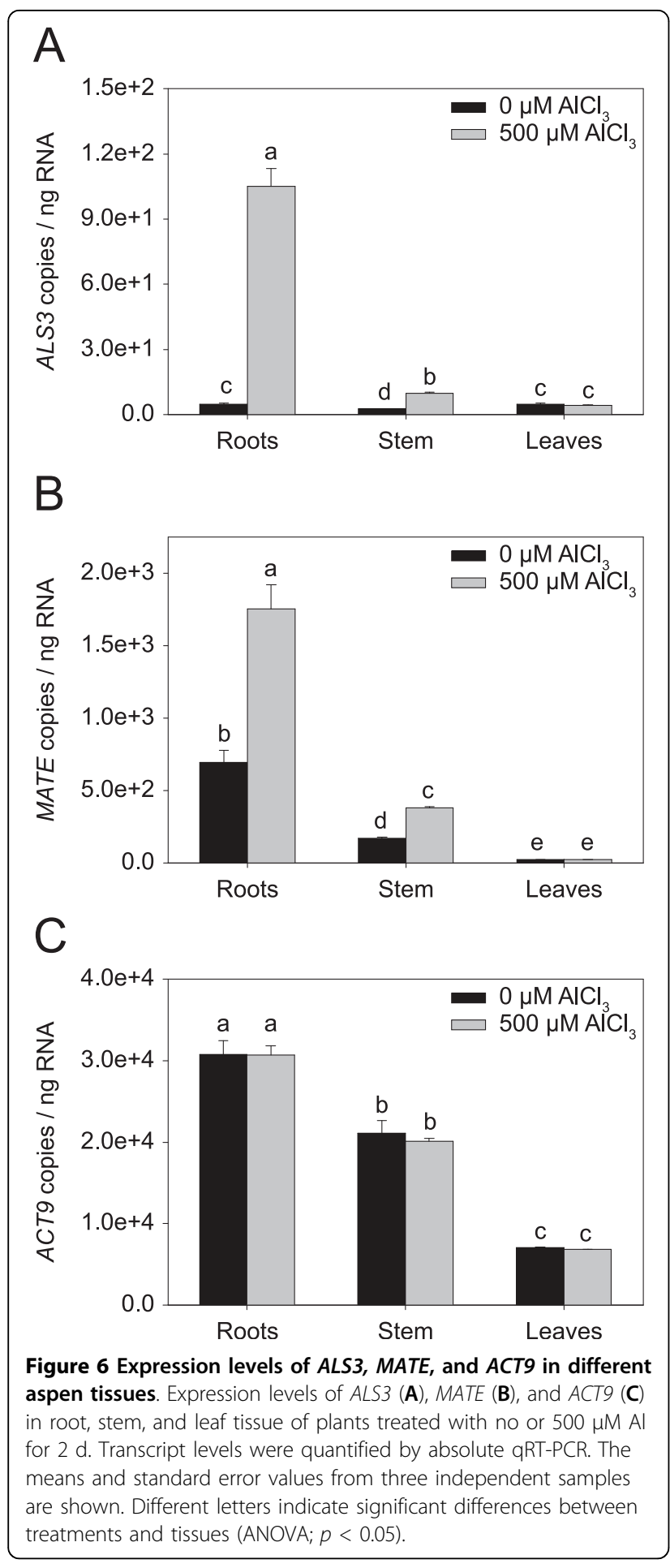

a lower extent in the stem (3.9-fold), while MATE was induced both in the root (2.5-fold) and in the stem (2.3fold). The expression levels of ACT9 did not differ between the treatments, but did between the tissues, where they were highest in the root (Fig. 6C). However, the differences in $A C T 9$ expression in the different tissues did not explain the tissue-specific expression of $A L S 3$ and $M A T E$, as was shown by plotting transcript levels relative to ACT9 (data not shown). Taken together, expression patterns of the two aspen genes were highly coherent with that of the Arabidopsis ALS3 and MATE.

To examine whether $\mathrm{Al}$ induces the two genes in a concentration-dependent way, a separate set of plants were treated with increasing concentrations of $\mathrm{Al}$ up to $1000 \mu \mathrm{M}$ Al. Plants were also treated with increasing concentrations of lanthanum (La), which has chemical properties similar to those of $\mathrm{Al}$ and is known to inhibit root growth [44]. Root growth measurements showed that $\mathrm{La}$ inhibited root growth in a similar way to $\mathrm{Al}$, but the inhibition was stronger (data not shown). Absolute qRT-PCR showed that the expression of both genes increased with $\mathrm{Al}$ in the medium (Fig. 7A; B). In contrast, exposure of the roots to La induced $M A T E$, but not ALS3 (Fig. 7A; B). Based on levels of ACT9 expression, it appeared that La concentrations $\geq 250 \mu \mathrm{M}$, affected transcription (Fig. 7C).

\section{Discussion}

In this study, we analyzed temporal patterns of root growth and root gene expression in aspen under $\mathrm{Al}$ stress. Two phases of root growth could be distinguished: a rapid Al-induced growth inhibition (within $6 \mathrm{~h}$ ) and a subsequent growth recovery. From our analysis of gene expression at three time points, we found a pronounced decrease in the number of responsive genes from 202 to 27 between $6 \mathrm{~h}$ and $2 \mathrm{~d}$ of Al exposure. The number of changes then remained low. Similar patterns of root growth and gene expression were observed in an Al-tolerant line of Medicago truncatula [28]. The root growth of this line largely recovered within $2 \mathrm{~d}$ of $\mathrm{Al}$ exposure, while that of an Al-sensitive line remained inhibited. The number of responsive genes was found to decrease in both lines between $12 \mathrm{~h}$ and $2 \mathrm{~d}$ of $\mathrm{Al}$ exposure, but the reduction was stronger in the Al-tolerant line (3.3-fold) than in the Al-sensitive line (1.5-fold). These patterns may reflect the success of roots in activating Al tolerance mechanisms and the restoration of the transcriptome to a prestress program, and in the case of the Al-sensitive line of Medicago the failure to establish an adaptive response.

Consistent with the strong Al-induced root growth inhibition at the $6 \mathrm{~h}$ time point, a number of differentially expressed genes can be associated with toxic effects of Al. Our enrichment analysis identified cell wall modification, ion transport, and oxidative stress as major biological processes operating at this time point. The regulation of cell wall-related genes was not surprising because the cell wall is considered to be a major site of Al toxicity [4]. Physiological studies show consistently that a large 


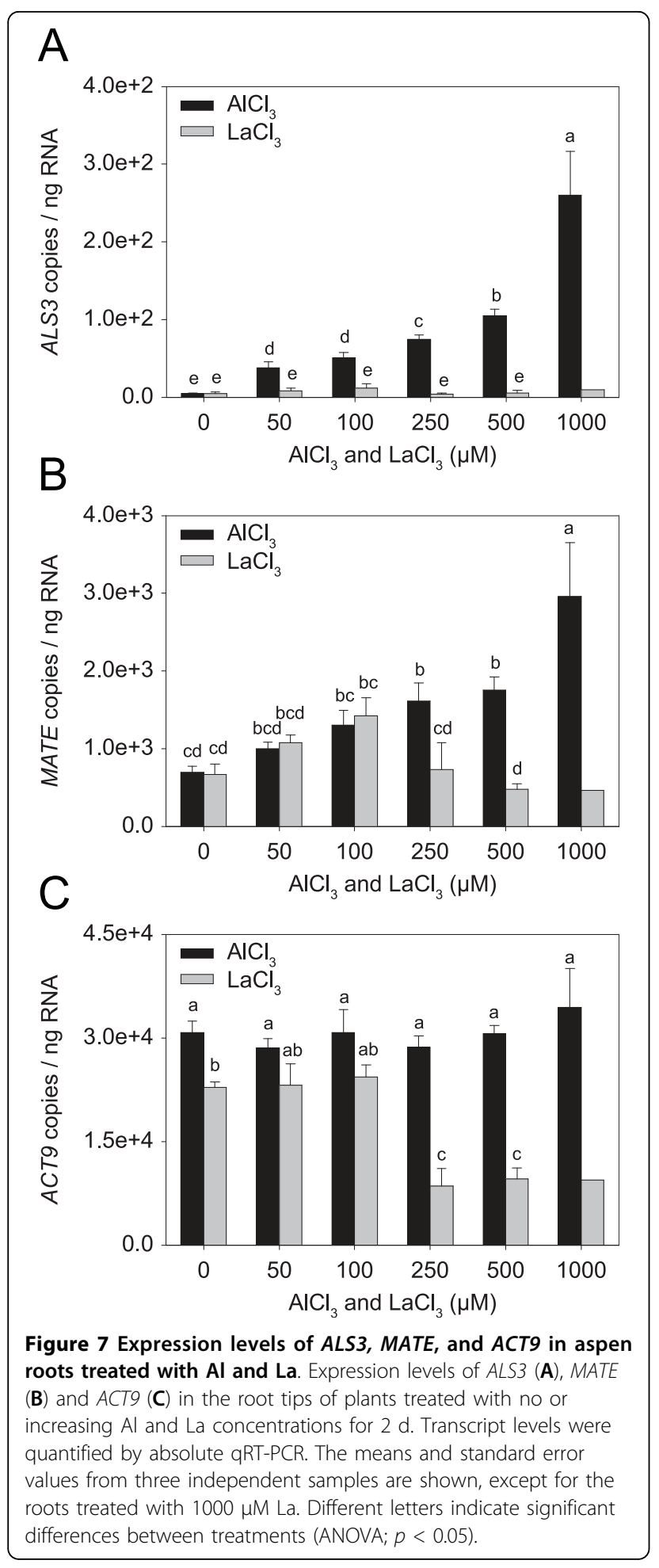

portion of the $\mathrm{Al}$ absorbed by roots is localized to the apoplasm [5]. Several studies indicate that the Al bound to the apoplasm can make the cell wall more rigid, thus reducing its extensibility, which is required for normal cell extension $[45,46]$. Plants are believed to employ several different mechanisms to loosen the cell wall during cell extension. Proposed cell wall loosening agents include expansin, xyloglucan endotransglucosylase/ hydrolase (XHT), endo-1,4- $\beta$-glucanase, and hydroxyl radicals [47]. In this study, we recorded several genes encoding XHTs and endo-1,4- $\beta$-glucanases, with some of the genes being up-regulated and others being downregulated. These contrasting responses may reflect the different enzymatic functions that members of the XHT and endo-1,4- $\beta$-glucanase protein families can fulfill [47]. Although the exact function of the XHT and endo-1,4- $\beta$ glucanase genes identified is not known, it appears likely that these genes play a role in minimizing the toxic effects of $\mathrm{Al}$ on the cell wall. A number of physiological studies demonstrate that $\mathrm{Al}$ strongly interacts with membrane channel proteins, resulting in the disruption of the uptake and homeostasis of cations, such as $\mathrm{Ca}, \mathrm{Mg}$, and $\mathrm{K}$ [3]. In our study, we recorded up-regulation of a twopore $\mathrm{K}^{+}$channel gene and two CorA-like $\mathrm{Mg}$ transporter genes, indicating that $\mathrm{Al}$ interferes with $\mathrm{K}$ and $\mathrm{Mg}$ homeostasis in aspen roots. $\mathrm{Mg}$ transporters have so far not been found to be $\mathrm{Al}$ inducible. Nevertheless, two lines of evidence indicate that $\mathrm{Mg}$ transporters play an important role in $\mathrm{Al}$ toxicity. The activity of a CorA-like $\mathrm{Mg}$ transporter of Arabidopsis was shown to be blocked by micromolar concentrations of $\mathrm{Al}$ [38]. In addition, the same CorA-like $\mathrm{Mg}$ transporter alleviated Al toxicity when overexpressed in planta [48]. Although oxidative stress is commonly regarded to be a major component of $\mathrm{Al}$ toxicity, we recorded only a small number of genes belonging to the ROS network of genes. A Fe superoxide dismutase and a mitochondrial alternative oxidase gene were upregulated. While Fe superoxide dismutases are responsible for ROS scavenging [49], alternative oxidases serve to lower mitochondrial ROS formation [50]. Induction of the alternative oxidase is entirely in agreement with the finding that $\mathrm{Al}$ can induce $\mathrm{ROS}$ formation in mitochondria [51].

Based on information from Arabidopsis and crop plants, three differentially expressed aspen genes may play a role in $\mathrm{Al}$ tolerance mechanisms. Two genes were closely related to the Arabidopsis Al tolerance genes $A L S 3$ and MATE. Patterns of expression in different plant organs and in response to $\mathrm{Al}$ strongly suggest that the two aspen genes are homologs of the Arabidopsis ALS3 and MATE. The exact function of the Arabidopsis $A L S 3$ is not known. Mutant als3 seedlings grown in Alcontaining medium exhibit a severe arrest of root growth and inhibited leaf expansion [52]. Based on this phenotype and patterns of tissue-specific expression, ALS3 has been proposed to mediate transport of $\mathrm{Al}$ away from sensitive root tissues to aerial parts of the plant for sequestration or exudation [23]. The Arabidopsis ALS3 is expressed in the phloem throughout the plant and is 
strongly induced by $\mathrm{Al}$ in the root cortex [23]. Our aspen $A L S 3$ gene was expressed in the root, stem, and leaves, and was strongly induced by $\mathrm{Al}$ in the root. In addition, the aspen $A L S 3$ was inducible by $\mathrm{Al}$, but not by La. This is consistent with the finding that the Arabidopsis mutant als3 is not affected by La [52]. Based on information from Arabidopsis, it appears likely that the aspen gene identified is functioning in internal $\mathrm{Al}$ tolerance. The predicted aspen ALS3 also shared significant sequence identity with STAR2 of rice, which has been suggested to be involved in masking $\mathrm{Al}$ binding sites at the cell wall. However, since STAR2 is expressed in the root only [21], it seems unlikely that the aspen gene is a homolog of STAR2. The second putative aspen Al tolerance gene belongs to the MATE gene family. Members of this gene family mediate the release of citrate into the rhizosphere and have been demonstrated to represent major genes of Al tolerance in several plant species [8]. The aspen $M A T E$ was primarily expressed in the root and was inducible by Al, a pattern comparable to that of the Arabidopsis MATE and MATE of other plant species [16-20]. Previously, we have shown that aspen releases citrate and oxalate from roots in response to $\mathrm{Al}$ exposure. Therefore, it is possible that the aspen MATE is involved in the release of citrate and that this mechanism is regulated at least in part at the transcriptional level. An additional aspen gene that may play a role in $\mathrm{Al}$ tolerance encodes a pectin methylesterase. This gene was down-regulated early in the response to Al. Pectin methylesterases demethylate pectin and thereby generate free pectin carboxylic groups. The degree of pectin demethylation largely determines the negative charge the pectin matrix carries and thus the amount of Al that can bind to the cell wall. In maize and rice, the degree of pectin methylation has been linked to genotypic differences in $\mathrm{Al}$ tolerance. It was demonstrated that the root tips of Alsensitive lines had a lower degree of pectin methylation and that larger amounts of $\mathrm{Al}$ were bound to the cell wall when compared with Al-tolerant lines [11,12]. Consistent with this, higher levels of pectin methylesterase expression were observed in an Al-sensitive maize line than in an Al-tolerant line [26]. Down-regulation of the aspen pectin methylesterase gene thus may serve to reduce $\mathrm{Al}$ binding sites at the pectin matrix, and consequently to limit accumulation of $\mathrm{Al}$ in the apoplasm.

\section{Conclusion}

This study shows that aspen roots respond to $\mathrm{Al}$ exposure with a rapid inhibition of root growth and a large change in gene expression. This early response to $\mathrm{Al}$ was characterized by genes involved in cell wall modification, ion transport, and oxidative stress. The subsequent root growth recovery and the concomitant reduction in responsive genes strongly suggest that aspen roots are capable to activate $\mathrm{Al}$ tolerance mechanisms when exposed to Al. Based on information from Arabidopsis and other plant species, it appears likely that $A L S 3, M A T E$, and possibly a pectin methylesterase gene are important components of the $\mathrm{Al}$ tolerance mechanisms in aspen. These genes and genes with unknown function provide candidates for further studies to elucidate the molecular basis of $\mathrm{Al}$ tolerance in aspen.

\section{Methods}

\section{Plant material}

Experiments were performed with in vitro propagated plants of the aspen (Populus tremula L.) clone Birmensdorf [33]. The plants were maintained in Magenta vessels (GA-7) on $80 \mathrm{ml}$ of $1 / 2 \mathrm{MS}$ medium (Murashige and Skoog), supplemented with $1 \%$ sucrose and solidified with $0.8 \%$ agar. The plants were cultivated in a greenhouse and multiplied every 6-8 weeks.

\section{Solution culture experiments}

Aspen roots were treated with $\mathrm{Al}$ and $\mathrm{La}$ in solution culture prepared in modified Magenta vessels (GA-7). Teflon-racks, placed on the floor of the vessels, supported a $1190 \mu \mathrm{m}$ nylon mesh (Sefar) as substrate for the plants and two glass slides with a $5 \mu \mathrm{m}$ grid $\left(\mathrm{N}^{\circ} 5\right.$, Boraglas) used as a reference to measure root growth. The modified Magenta vessels were sterilized by autoclaving, and filled with $120 \mathrm{ml}$ of autoclaved 1/6 MS solution (pH 4.0) containing $50 \mathrm{nM}$ indol-3-butyric acid (IBA) to induce and synchronize root formation [53]. In each vessel, four cuttings with 3-4 internodes and 1-2 apical leaves were inserted into the mesh so that the roots could form between the wall of the vessel and the glass slide (slotted 1 $\mathrm{cm}$ away of the vessel wall). After one day, the nutrient solution was replaced with fresh 1/6 MS medium ( $\mathrm{pH}$ 4.0) without IBA. The cuttings were incubated without aeration in a climate chamber maintained at $20 \pm 2^{\circ} \mathrm{C}$ with a $16 \mathrm{~h}$ light/8 h darkness period (Osram Dulux L 36W/840 color white, Osram). The nutrient solution was replaced twice a week. After $20 \mathrm{~d}$ of incubation, after the cuttings had formed 5-15 adventitious roots, the nutrient solution was replaced with treatment solution composed of autoclaved 1/6 MS medium ( $\mathrm{pH} 4.0$ ), supplemented with increasing concentrations of filter-sterilized $\mathrm{AlCl}_{3}$ up to $1000 \mu \mathrm{M}$ (dissolved in 1/6 MS). The $\mathrm{pH}$ of the Al treatment solutions was adjusted prior to $\mathrm{Al}$ addition with filter-sterilized base $(1 \mathrm{M} \mathrm{KOH})$ at amounts empirically determined to ensure that the final $\mathrm{pH}$ was 4.0. Treatment experiments with $\mathrm{LaCl}_{3}$ were identical to those carried out with $\mathrm{AlCl}_{3}$.

The root growth was monitored photographically prior to the treatment $(2 \mathrm{~d})$ and during the entire treatment at $12 \mathrm{~h}$ intervals and during the first day of the treatment at $6 \mathrm{~h}$ intervals. We used a Canon EOS $400 \mathrm{D}$ 
digital camera fitted with a Canon macro lens EF 100 $\mathrm{mm}$ focused on the $5 \mu \mathrm{m}$ grid of the glass slides. Files were transferred to an Apple MacBookPro, and the pictures were cropped and normalized using the grid on the glass slide with IMAGEJ 1.36b for Macintosh http:// rsb.info.nih.gov/ij/. The normalized pictures were used to measure the increase in root length during the particular time intervals. The root growth rate was estimated by dividing each increment by the time elapsed.

Following these treatments, the roots were separated from the shoots and were rinsed in 1/6 MS pH 4.0. The first centimeter of each root was collected, and all the roots processed per plant were transferred to a sterile $1.5 \mathrm{ml}$ tube. The pooled leaves and the stem were collected separately. All the tissues were frozen in liquid nitrogen and stored at $-80^{\circ} \mathrm{C}$ until RNA extraction.

\section{Quantification of callose}

Callose was quantified in the first centimeter of the roots essentially as described by Köhle et al. [54]. Ethanol-fixed root tips (four per plant) were blotted dry and homogenized in $0.5 \mathrm{ml}$ of $1 \mathrm{M} \mathrm{NaOH}$ with two steel beads in a Retsch MM 200 mixing mill for 3 min. The homogenate was supplemented with $0.5 \mathrm{ml}$ of $1 \mathrm{M} \mathrm{NaOH}$ and incubated at $80^{\circ} \mathrm{C}$ for $30 \mathrm{~min}$. Following centrifugation, $200 \mu \mathrm{l}$ of the supernatant were mixed with $400 \mu \mathrm{l}$ of $0.1 \%(\mathrm{w} / \mathrm{v})$ aniline blue and $1 \mathrm{M}$ glycine $\mathrm{NaOH}$ buffer ( $\mathrm{pH}$ 9.5), and incubated at $50^{\circ} \mathrm{C}$ for $20 \mathrm{~min}$. Callose was quantified fluorometrically at $400 \mathrm{~nm}$ excitation and at 512-521 nm emission wavelength (FluroLog FL3-22, Jobin Yvon), using curdlan as a reference.

\section{Treatment of plants used for gene expression profiling} Gene expression profiles were determined in a single set of clonal plants grown simultaneously to produce RNA. The plants were treated with no or $500 \mu \mathrm{M} \mathrm{AlCl}_{3}$ for $6 \mathrm{~h}, 54 \mathrm{~h}$, and $246 \mathrm{~h}$. For each treatment period, three solution cultures were established to allow three independent plants per treatment to be analyzed. Following treatment, the roots were processed as described above and stored at $-80^{\circ} \mathrm{C}$ until RNA extraction. To control the $\mathrm{Al}$ concentrations in the nutrient solutions, total $\mathrm{Al}$ was quantified by inductively coupled plasma optical emission (ICP-OES; Optima 7300 DV, Perkin Elmer, Wellesley, MA). Prior to analysis, the samples were acidified with nitric acid at $1.5 \%(\mathrm{v} / \mathrm{v})$.

\section{RNA isolation}

Total RNA from the root tips, stems and leaves were isolated with the Agilent Total RNA Isolation Mini-Kit (Agilent Technologies) according to the manufacturer's instructions. Steps 10 and 11 of the protocol (Agilent Technologies, 2005) were modified as follows: step 10 was carried out twice with $400 \mu \mathrm{l}$ of wash solution, and step 11 with $400 \mu \mathrm{l}$ and centrifugation for $1 \mathrm{~min}$, followed by an additional centrifugation for $1 \mathrm{~min}$ to ensure that the membrane of the column was completely dry. The concentration of total RNA was determined with a Nanodrop ND-1000 spectrophotometer and the integrity of the RNA was determined with the Eukaryote Total RNA Nano Assay (Agilent Technologies) using the 2100 Agilent Bioanalyzer. Only RNAs with a $260 \mathrm{~nm} / 280 \mathrm{~nm}$ ratio between 1.8 and 2.1 and a RNA integrity number between 7 and 10 were processed further.

\section{Microarray analyses}

Microarray analyses were carried out with the Affymetrix GeneChip poplar genome array, which was designed based on sequence information from different poplar species. Synthesis of cDNA, cRNA labeling, and hybridization to the GeneChip poplar genome array were essentially performed as described in the Affymetrix GeneChip Expression Analysis Technical Manual (2005). The cDNA synthesis was performed with $2 \mu \mathrm{g}$ of total RNA, and the quality of the labeled cRNA was determined using Bioanalyzer 2100.

After hybridization and scanning, probe cell intensities were calculated with the Affymetrix Microarray Analysis Suite (MAS version 5.0) [55]. The Robust Multichip Average (RMA) summary algorithm [56] as implemented in GeneSpring GX 7.3 (Agilent Technologies Inc.) was used to generate and normalize raw gene expression data from probe intensities. Genespring was also used to filter out normalized expression values when not showing present calls in all replicate measurements of at least one condition. To identify genes whose expression differed upon $\mathrm{Al}$ treatment at each time point, a Student's t-test was performed in R http://www.r-project.org. To reduce the number of true discoveries that include false positives in multiple and simultaneous statistical tests, a positive false discovery rate (FDR), called $q$, was estimated for each gene. $Q$-values were calculated with the QVALUE software (implemented in $\mathrm{R})$ with the $p$-values $(p<0.05$, obtained from the t-test) as input and the bootstrap robust settings [34]. Genes were considered to be differentially expressed when (1) the transcript abundance in Al-treated plants was significantly different from that of control plants as determined by the Student's t-test, (2) the calculated $q$ was $\leq$ 0.15 , and (3) the change in expression between treated and control plants was at least two-fold. Probe-sets matching the same gene model of the black cottonwood genome sequence http://www.phytozome.net/poplar were declared as redundant. Microarray data are available in the Gene Omnibus Database as accessions GSE19297.

To annotate the expressed transcripts, we performed BLASTX searches against the Arabidopsis protein database (TAIR; http://www.arabidopsis.org). The best match was reported, and the resulting list of Arabidopsis 
identifiers was applied to the Functional Catalogue developed by MIPS http://mips.gsf.de/proj/funcatDB to identify biological processes. The MIPS singular enrichment tool was used to identify categories whose members were statistically over-represented compared to the genes present on the microarray. The frequency of genes of a given category on the microarray was calculated as the ratio of the number of genes of this category divided by the total number of genes on the microarray, and the frequency of regulated genes of a given category was calculated as the ratio of the number of regulated genes of this category divided by the total number of regulated genes. Because differentially expressed genes were annotated based on information from Arabidopsis, we only considered genes of the microarray representing putative homologs of Arabidopsis genes (15,216 genes). Our significance test to search for enriched categories was based on the hypergeometric distribution and is identical to the corresponding one-tailed version of Fisher's exact test, calculating the probability of observing data as extreme or more extreme if the null hypothesis is true. Two strategies to correct for multiple testing were used. The first was Bonferroni's correction, which is a conservative way to control the family wise error rate, and the second a FDR. Functional categories with a $p$-value < 0.05 and a FDR $<0.05$ were regarded to be enriched.

\section{Real-time reverse transcription PCR}

Real-time reverse transcription PCR (qRT-PCR) was performed with primers matching aspen sequences that were obtained as follows. Sequence information on the Affymetrix probes was used to design primers, which amplified as long fragments as possible. These primers were applied in RT-PCR and the resulting RTPCR products were directly sequenced. The aspen sequences obtained were then used to design new primers, which amplified short fragments suitable for qRT-PCR (90-114 bp). When possible, one of the two primers was designed across an exon-exon junction using information from the black cottonwood genome sequence. Primers were designed with the Primer3 software [57]. Sequences of the primers are given in additional file 3 .

To validate the results of the microarray analysis, we quantified the expression of eight genes relative to ACT9. RT was performed with $200 \mathrm{ng}$ of total RNA using the QuantiTect Reverse Transcription Kit (Qiagen) under conditions recommended by the manufacturer. PCR was performed with the power SYBR green PCR master mix (Applied Biosystems) in a reaction volume of $25 \mu \mathrm{l}$ containing $5 \mu \mathrm{l}$ of diluted cDNA. Cycling was carried out on an ABI 7500 Fast real-time cycler (Applied Biosystems) with the following cycling profile: 10 min activation of AmpliTaq Gold Polymerase at $95^{\circ} \mathrm{C}, 45$ cycles of $15 \mathrm{sec}$ denaturation at $95^{\circ} \mathrm{C}$, $30 \mathrm{sec}$ annealing at $60^{\circ} \mathrm{C}, 30 \mathrm{sec}$ extension at $72^{\circ} \mathrm{C}$, followed by a dissociation step of $15 \mathrm{sec}$ at $95^{\circ} \mathrm{C}, 15 \mathrm{sec}$ at $60^{\circ} \mathrm{C}$, and $15 \mathrm{sec}$ at $95^{\circ} \mathrm{C}$ to detect primer dimers and non-specific amplification products. For each primer pair, we determined the PCR efficiency and the dynamic range of PCR by plotting the threshold cycle $\left(C_{t}\right)$ values generated over a range of dilutions against the log input of cDNA amount. To obtain accurate results, only primer pairs yielding PCR efficiencies of 90-110\% (slope of regression between -3.2 and -3.5) were considered [58]. To quantify the transcripts, each cDNA of three biological replicates was diluted in duplicate and used in duplicate PCR. The relative abundance of each transcript was estimated using the $\Delta \Delta C_{t}$ method [59].

The expression of selected genes (ALS3, MATE, and $A C T 9$ ) was further quantified by absolute qRT-PCR. Copy numbers of the transcripts were calculated from standard curves that were obtained as follows. Singlestranded sense olignonucleotides specifying amplicons of the selected genes were synthesized (Operon; for sequences see additional file 4). Information from the manufacturer was used to calculate the copy number of the oligonucleotides present in $1 \mu \mathrm{l}$ of $10 \mathrm{mM}$ Tris- $\mathrm{HCl}$ $\mathrm{pH} 8.5$ (Qiagen). Serial dilutions of the stocks were carried out in duplicate, and dilutions in the range from $10^{2}-10^{8}$ copies were used in duplicate PCR to generate standard curves. The standard curve was obtained by plotting the logs of the calculated copy number against $\mathrm{C}_{\mathrm{t}}$. The copy numbers of unknown samples were calculated from the regression line. Each cDNA was diluted and run in duplicate, and the transcript copy number was expressed per nanogram of total RNA.

\section{Additional material}

Additional file 1: List of Al-responsive genes in root tips of aspen.
Additional file 2: Lists of MIPS categories whose genes were
significantly enriched ( $p<0.05 ;$ FDR $<0.05)$.
Additional file 3: Primers used to perform real-time reverse
transcription PCR in aspen.
Additional file 4: Sequences of single-stranded sense
oligonucleotides specifying amplicons of ACT9, ALS3, and MATE of
aspen.

\section{Acknowledgements}

We thank Daniela Steiner for her help in our laboratory and in propagating aspen. We also thank Enrico Martinoia for helpful discussions, Ulrich Wagner for suggestions about the design and data analysis of test microarray experiments, and Silvia Dingwall for improving the English. The work was partially founded by the State Secretariat for Education and Research (SER; grant C04.0259 to CS, LB, IB) through the COST E38 Action 'Woody root processes' and by the European Network of Excellence EVOLTREE supporting courses for $\mathrm{NG}$. 


\section{Author details}

'Swiss Federal Institute for Forest, Snow and Landscape Research (WSL), Zürcherstrasse 111, CH-8903 Birmensdorf, Switzerland. ${ }^{2}$ Functional Genomics Center Zurich, University of Zurich and Swiss Federal Institute of Technology Zurich, Winterthurerstrasse 190, CH-8057 Zurich, Switzerland. ${ }^{3}$ Institute of Chemistry and Biological Chemistry, Zurich University of Applied Sciences, School of Life Sciences and Facility Management, Einsiedlerstrasse 31, CH8820 Wädenswil, Switzerland. ${ }^{4}$ Institute of Bioinformatics and System Biology, Helmholtz Center Munich, Ingolstädter Landstraße 1, D-85764 Neuherberg, Germany. ${ }^{5}$ Department of Biology, University of Fribourg, Chemin du Musée 10, CH-1700 Fribourg, Switzerland. ${ }^{6}$ Genetic Diversity Centre, Swiss Federal Institute of Technology, Universitätstrasse 16, CH-8092 Zurich, Switzerland. ${ }^{7}$ Dualsystems Biotech AG, Grabenstrasse 11a, CH-8952 Schlieren, Switzerland. ${ }^{8}$ Philip Morris International Research \& Development, Philip Morris Products SA, Quai Jeanrenaud 56, CH-2000 Neuchâtel, Switzerland.

\section{Authors' contributions}

NG carried out the molecular and plant studies, participated in the microarray data analysis, and drafted the manuscript. MGK carried out the screening of the microarrays, SZ performed the statistical analysis of the microarray data, and MM performed the enrichment analysis. TL quantified the callose and participated in the plant studies. IB, LB, and JPM participated in the design of the study and improved the quality of the manuscript. CS coordinated the study and wrote the final manuscript. All authors have read and approved the final manuscript.

Received: 16 September 2009 Accepted: 23 August 2010 Published: 23 August 2010

\section{References}

1. Ryan PR, Ditomaso JM, Kochian LV: Aluminium toxicity in roots: an investigation of spatial sensitivity and the role of the root cap. Journal of Experimental Botany 1993, 44:437-446.

2. Sivaguru $M$, Horst WJ: The distal part of the transition zone is the most aluminum-sensitive apical root zone of maize. Plant Physiology 1998, 116:155-163.

3. Kochian LV, Piñeros MA, Hoekenga OA: The physiology, genetics and molecular biology of plant aluminum resistance and toxicity. Plant and Soil 2005, 274:175-195.

4. Horst WJ, Wang Y, Eticha D: The role of the root apoplast in aluminiuminduced inhibition of root elongation and in aluminium resistance of plants: a review. Annals of Botany 2010, 106:185-197.

5. Ma JF: Syndrome of aluminum toxicity and diversity of aluminum resistance in higher plants. International Review of Cytology 2007 264:225-252.

6. Rounds MA, Larsen PB: Aluminum-dependent root-growth inhibition in Arabidopsis results from AtATR-regulated cell-cycle arrest. Current Biology 2008, 18:1495-1500.

7. Kochian LV, Hoekenga OA, Piñeros MA: How do crop plants tolerate acid soils? Mechanisms of aluminum tolerance and phosphorous efficiency. Annual Review of Plant Biology 2004, 55:459-493.

8. Delhaize $E$, Gruber BD, Ryan PR: The roles of organic anion permeases in aluminium resistance and mineral nutrition. FEBS Letters 2007, 581:2255-2262.

9. Basu U, Basu A, Taylor GJ: Differential exudation of polypeptides by roots of aluminum-resistant and aluminum-sensitive cultivars of Triticum aestivum L. in response to aluminum stress. Plant Physiology 1994, 106:151-158

10. Degenhardt J, Larsen PB, Howell SH, Kochian LV: Aluminum resistance in the Arabidopsis mutant alr-104 is caused by an aluminum-induced increase in rhizosphere pH. Plant Physiology 1998, 117:19-27.

11. Eticha D, Stass A, Horst WJ: Cell-wall pectin and its degree of methylation in the maize root-apex: significance for genotypic differences in aluminium resistance. Plant, Cell and Environment 2005, 28:1410-1420.

12. Yang $J L, L i$ YY, Zhang YJ, Zhang SS, Wu YR, Wu P, Zheng SJ: Cell wall polysaccharides are specifically involved in the exclusion of aluminum from the rice root apex. Plant Physiology 2008, 146:602-611.

13. Sasaki T, Yamamoto Y, Ezaki B, Katsuhara M, Ahn SJ, Ryan PR, Delhaize E, Matsumoto H: A wheat gene encoding an aluminum-activated malate transporter. Plant Journal 2004, 37:645-653.
14. Hoekenga OA, Maron LG, Piñeros MA, Cançado GMA, Shaff J, Kobayashi Y, Ryan PR, Dong B, Delhaize E, Sasaki T, et al: AtALMT1, which encodes a malate transporter, is identified as one of several genes critical for aluminum tolerance in Arabidopsis. Proceedings of the National Academy of Sciences of the United States of America 2006, 103:9738-9743.

15. Ligaba A, Katsuhara M, Ryan PR, Shibasaka M, Matsumoto H: The BnALMT1 and BnALMT2 genes from rape encode aluminum-activated malate transporters that enhance the aluminum resistance of plant cells. Plant Physiology 2006, 142:1294-1303.

16. Magalhaes JV, Liu J, Guimarães CT, Lana UGP, Alves VMC, Wang YH, Schaffert RE, Hoekenga OA, Piñeros MA, Shaff JE, et al: A gene in the multidrug and toxic compound extrusion (MATE) family confers aluminum tolerance in sorghum. Nature Genetics 2007, 39:1156-1161.

17. Furukawa J, Yamaji N, Wang H, Mitani N, Murata Y, Sato K, Katsuhara M, Takeda K, Ma JF: An aluminum-activated citrate transporter in barley. Plant and Cell Physiology 2007, 48:1081-1091.

18. Liu J, Magalhaes JV, Shaff J, Kochian LV: Aluminum-activated citrate and malate transporters from the MATE and ALMT families function independently to confer Arabidopsis aluminum tolerance. Plant Journal 2009, 57:389-399.

19. Ryan PR, Raman H, Gupta S, Horst WJ, Delhaize E: A second mechanism for aluminum resistance in wheat relies on the constitutive efflux of citrate from roots. Plant Physiology 2009, 149:340-351.

20. Maron LG, Piñeros MA, Guimarães CT, Magalhaes JV, Pleiman JK, Mao C, Shaff J, Belicuas SNJ, Kochian LV: Two functionally distinct members of the MATE (multi-drug and toxic compound extrusion) family of transporters potentially underlie two major aluminum tolerance QTLs in maize. Plant Journal 2010, 61:728-740.

21. Huang CF, Yamaji N, Mitani N, Yano M, Nagamura Y, Ma JF: A bacterialtype $A B C$ transporter is involved in aluminum tolerance in rice. Plant Cell 2009, 21:655-667.

22. Larsen PB, Cancel J, Rounds M, Ochoa V: Arabidopsis ALS1 encodes a root tip and stele localized half type $A B C$ transporter required for root growth in an aluminum toxic environment. Planta 2007, 225:1447-1458.

23. Larsen PB, Geisler MJB, Jones CA, Williams KM, Cancel JD: ALS3 encodes a phloem-localized $A B C$ transporter-like protein that is required for aluminum tolerance in Arabidopsis. Plant Journal 2005, 41:353-363.

24. Kumari M, Taylor GJ, Deyholos MK: Transcriptomic responses to aluminum stress in roots of Arabidopsis thaliana. Molecular Genetics and Genomics 2008, 279:339-357.

25. Goodwin SB, Sutter TR: Microarray analysis of Arabidopsis genome response to aluminum stress. Biologia Plantarum 2009, 53:85-99.

26. Maron LG, Kirst M, Mao C, Milner MJ, Menossi M, Kochian LV: Transcriptional profiling of aluminum toxicity and tolerance responses in maize roots. New Phytologist 2008, 179:116-128.

27. Houde M, Diallo AO: Identification of genes and pathways associated with aluminum stress and tolerance using transcriptome profiling of wheat near-isogenic lines. BMC Genomics 2008, 9:400.

28. Chandran D, Sharopova N, VandenBosch KA, Garvin DF, Samac DA: Physiological and molecular characterization of aluminum resistance in Medicago truncatula. BMC Plant Biology 2008, 8:89.

29. Schaedle M, Thornton FC, Raynal DJ, Tepper HB: Response of tree seedlings to aluminum. Tree Physiology 1989, 5:337-356.

30. Göransson A, Eldhuset TD: Effects of aluminium on root growth and nutrient uptake of Betula pendula seedlings. Physiologia Plantarum 1987, 69:193-199.

31. Göransson A, Eldhuset TD: Effects of aluminium on root growth and nutrient uptake of small Picea abies and Pinus sylvestris plants. TreesStructure and Function 1991, 5(3):136-142.

32. Brauer D: Rapid inhibition of root growth in wheat associated with aluminum uptake as followed by changes in morin fluorescence. Journal of Plant Nutrition 2001, 24:1243-1253.

33. Qin R, Hirano $Y$, Brunner I: Exudation of organic acid anions from poplar roots after exposure to Al, Cu and Zn. Tree Physiology 2007, 27:313-320.

34. Storey JD, Tibshirani R: Statistical significance for genomewide studies. Proceedings of the National Academy of Sciences of the United States of America 2003, 100:9440-9445.

35. Klein D: Quantification using real-time PCR technology: applications and limitations. Trends in Molecular Medicine 2002, 8:257-260.

36. Ruepp A, Zollner A, Maier D, Albermann K, Hani J, Mokrejs M, Tetko I, Güldener U, Mannhaupt G, Münsterkötter M, Mewes HW: The FunCat, a 
functional annotation scheme for systematic classification of proteins from whole genomes. Nucleic Acids Research 2004, 32:5539-5545.

37. Gobert A, Isayenkov S, Voelker C, Czempinski K, Maathuis FJM: The twopore channel TPK1 gene encodes the vacuolar $\mathrm{K}^{+}$conductance and plays a role in $\mathrm{K}^{+}$homeostasis. Proceedings of the National Academy of Sciences of the United States of America 2007, 104:10726-10731.

38. Li L, Tutone AF, Drummond RSM, Gardner RC, Luan S: A novel family of magnesium transport genes in Arabidopsis. Plant Cell 2001, 13:2761-2775.

39. Cubero B, Nakagawa Y, Jiang XY, Miura KJ, Li F, Raghothama KG, Bressan RA, Hasegawa PM, Pardo JM: The phosphate transporter PHT4;6 is a determinant of salt tolerance that is localized to the Golgi apparatus of Arabidopsis. Molecular Plant 2009, 2:535-552.

40. Kataoka T, Hayashi N, Yamaya T, Takahashi H: Root-to-shoot transport of sulfate in Arabidopsis. Evidence for the role of SULTR3;5 as a component of low-affinity sulfate transport system in the root vasculature. Plant Physiology 2004, 136:4198-4204.

41. Mittler R, Vanderauwera S, Gollery M, Van Breusegem F: Reactive oxygen gene network of plants. Trends in Plant Science 2004, 9:490-498.

42. Durrett TP, Gassmann W, Rogers EE: The FRD3-mediated efflux of citrate into the root vasculature is necessary for efficient iron translocation. Plant Physiology 2007, 144:197-205.

43. Rogers $\mathrm{EE}$, Guerinot ML: FRD3, a member of the multidrug and toxin efflux family, controls iron deficiency responses in Arabidopsis. Plant Cell 2002, 14:1787-1799.

44. Kinraide $T B$, Ryan PR, Kochian $L V$ : Interactive effects of $\mathrm{Al}^{3+}, \mathrm{H}^{+}$, and other cations on root elongation considered in terms of cell-surface electrical potential. Plant Physiology 1992, 99:1461-1468.

45. Tabuchi A, Matsumoto H: Changes in cell-wall properties of wheat (Triticum aestivum) roots during aluminum-induced growth inhibition. Physiologia Plantarum 2001, 112:353-358.

46. Jones DL, Blancaflor EB, Kochian LV, Gilroy S: Spatial coordination of aluminium uptake, production of reactive oxygen species, callose production and wall rigidification in maize roots. Plant, Cell and Environment 2006, 29:1309-1318.

47. Cosgrove DJ: Growth of the plant cell wall. Nature Reviews Molecular Cell Biology 2005, 6:850-861.

48. Deng W, Luo K, Li D, Zheng X, Wei X, Smith W, Thammina C, Lu L, Li Y, Pei $Y$ : Overexpression of an Arabidopsis magnesium transport gene, AtMGT1, in Nicotiana benthamiana confers Al tolerance. Journal of Experimental Botany 2006, 57:4235-4243.

49. Alscher RG, Erturk N, Heath LS: Role of superoxide dismutases (SODs) in controlling oxidative stress in plants. Journal of Experimental Botany 2002, 53:1331-1341.

50. Maxwell DP, Wang $Y$, Mclntosh $L$ : The alternative oxidase lowers mitochondrial reactive oxygen production in plant cells. Proceedings of the National Academy of Sciences of the United States of America 1999, 96:8271-8276.

51. Yamamoto Y, Kobayashi Y, Devi SR, Rikiishi S, Matsumoto H: Aluminum toxicity is associated with mitochondrial dysfunction and the production of reactive oxygen species in plant cells. Plant Physiology 2002, 128:63-72.

52. Larsen PB, Kochian LV, Howell SH: Al inhibits both shoot development and root growth in als3, an Al-sensitive Arabidopsis mutant. Plant Physiology 1997, 114:1207-1214.

53. Pythoud $F$, Buchala AJ: The fate of vitamin $\mathrm{D}_{3}$ and indolylbutyric acid applied to cuttings of Populus tremula L. during adventitious root formation. Plant, Cell and Environment 1989, 12:489-494.

54. Köhle H, Jeblick W, Poten F, Blaschek W, Kauss H: Chitosan-elicited callose synthesis in soybean cells as a $\mathrm{Ca}^{2+}$-dependent process. Plant Physiology 1985, 77:544-551.

55. Hubbell E, Liu WM, Mei R: Robust estimators for expression analysis. Bioinformatics 2002, 18:1585-1592.

56. Wu Z, Irizarry RA: Preprocessing of oligonucleotide array data. Nature Biotechnology 2004, 22:656-658.

57. Rozen S, Skaletsky H: Primer3 on the WWW for general users and for biologist programmers. In Bioinformatics Methods and Protocols: Methods in Molecular Biology. Edited by: Misener S, Krawetz SA. Totowa NJ: Humana Press; 2000:365-386.

58. Nolan T, Hands RE, Bustin SA: Quantification of mRNA using real-time RTPCR. Nature Protocols 2006, 1:1559-1582.
59. Livak KJ, Schmittgen TD: Analysis of relative gene expression data using real-time quantitative PCR and the $2^{-\Delta \Delta C T}$ method. Methods 2001, 25:402-408.

doi:10.1186/1471-2229-10-185

Cite this article as: Grisel et al:: Transcriptome responses to aluminum stress in roots of aspen (Populus tremula). BMC Plant Biology 2010 10:185.

\section{Submit your next manuscript to BioMed Central and take full advantage of:}

- Convenient online submission

- Thorough peer review

- No space constraints or color figure charges

- Immediate publication on acceptance

- Inclusion in PubMed, CAS, Scopus and Google Scholar

- Research which is freely available for redistribution

Submit your manuscript at www.biomedcentral.com/submit
Biomed Central 